\title{
IMAGE MANAGEMENT MODEL IN COMPANY CRISIS
}

\author{
Bintang Ayu Samniar \\ Communication Science Department \\ Universitas Muhammadiyah Surakarta \\ Email : bintangayu92@gmail.com
}

\begin{abstract}
For the sustainability of the company in Indonesia, triple bottom line concept (people, planet, profit) have to be adding in every company, especially mining company. This concept usually be realized by Corporate Social Responsibility (CSR) department, just like in PT Pamapersada Nusantara (PAMA) District KPCS, East Kalimantan. This research type is descriptive qualitative, which give readers explanation of the situation in facing crisis in 2010 by CSR PAMA KPCS. For explain this, writer used Crisis Pre-Emptive: Image Management Model by Augustine Pang, because the CSR concept which explored by writer is based on crisis which happen there, in 2010. In this study, writer divided the phase into 4 phases as the theory by Pang. They are: Before organizational event: proactive phase; Before organizational event: strategic phase; During organizational event: reactive phase; and After organizational event: recovery phase. Writer also make a scheme based on 4 phase above.
\end{abstract}

Keywords: CSR, Crisis, Image Management

\section{A. INTRODUCTION}

The crisis is the critical or crucial time, where the situation being turning point or vice versa (Soemirat, 2010: 182). Almost all companies are there, have experience of facing crisis like this. After the crisis, there are two possibilities that occur in the company, which is the state that is more conducive to good performance, as well as problems in the company that is getting worse. In business as in life, crises come in as many varieties as the common cold. The spectrum is so wide it is impossible to list each types (Regester, 2008: 139). However (Soemirat, 2010: 182), Philip Lesly crisis divides sources include:

1. Disasters such as fires, earthquakes, will affect the people inside and outside the company public as customers, agents, public investors, the community of a factory/ company;

2. Emergency condition that comes on suddenly or a development of this emergency condition such as product tampering, company or products that contain toxins. Planting bombs can cause panic and destruction or strike an employee of the company;

3. Bad rumors about the company or product;

4. The existence of such a burst of boycott from activists, government demand for attractive products (such as control of drug products not long ago), the kidnapping of a company executive;

The crisis experienced PT Pamapersada KPCS District can be categorized as a fourth type of crisis. That is the crisis that originated from the activities of activists.

PT Pamapersada Nusantara (Next: PT PAMA) is a multinational company engaged in mineral form of coal. The company is a contractor who scattered in as many as 16 branches throughout Indonesia. One of the subsidiaries, namely PT PAMA KPCS located in Sangatta, East Kutai, East Kalimantan. PT PAMA KPCS is a sub-contractor of PT Kaltim Prima Coal as an owner.

In 2010 is the one of another unforgettable year for KPC. Starting on Friday, March 5th2010, the company became 
the media spotlight as the Independent Voice demonstration filed by indigenous peoples to the KPC. Independent voice proclaim indigenous demos done in front of the external PT KPC as citizen angriness, because the company considered arrogant with no attention to a letter that was sent previously. Letter filed indigenous peoples is about improving the welfare of people, especially indigenous or local East Kutai. According to antaranews.com on March 22nd 2010 with the title "Masyarakat Adat Demo Kutim KPC", demos and involve around 150 indigenous peoples. They urged PT KPC in order to give a greater contribution to improving the welfare of local residents. Demo is done in the office and the East Kutai Parliament involving mothers and children. But nevertheless remained largely peaceful demonstrations. They demanded that the company with the nation's largest coal production (in 2010 is estimated at 70 million metric tons) provide a compensation fund of Rp 10,000 per metric ton of production. On that day they gave time to the PT Bumi Resources (owner of PT KPC) until March 25th, 2010. On May 11th, 2010 Liputan 6 broadcast the demo at KPC. Demo ongoing chaos and blockades occurred in the office of PT KPC. The chaos take place at the East Kutai Police officers forced open the blockade citizens. Residents feel not accept it because there is no definite answer to the demands of citizens related to $\mathrm{PT} K \mathrm{KPC}$ to contribute $\mathrm{Rp}$ 10,000 per one metric ton of production. This demo is a continuity of the previous demo on March 22nd, 2010.

The crisis is a sure thing happening in the company. At certain times of crisis is a turning point, after which the impact of the crisis can be good or bad for the company. The crisis is addressed to KPC in 2010, gives some effects, such as:

1. Occurred several times a demo in front of the external Swarga Bara, Sangatta Baru by people who called themselves the Alliance of Indigenous Peoples. One of the demo involving mothers and children;
2. Demo also resulted in checkpoint roadblock Ulin, Swarga Bara. Checkpoint, which is the only entry to the mine operator PT KPC along. This is clearly disturbing the operation of PT KPC;

3. One alternative street located in a residential Panorama, Swarga Bara towards the headquarters of PT KPC closed for security reasons. Therefore, some employees have to pass through the checkpoint first;

CSR PAMA KPCS eventually categorize the situation at the time as the condition of 'dangerous'. Next what PAMA KPCS treat to the crisis, is the effort to make the crisis as turning point at the company?

\section{B. IMAGE MANAGEMENT MODEL}

Johnson and Johnson defined Corporate Social Responsibility (CSR) is about how companies manage the business process to produce an overall positive impact on society. Lord Holme and Richard Watts define CSR is the continuing commitment by business to be have ethically and contribute to economic development while improving the quality of life of the workforce and their families as well as of the local community and society at large (Hadi, 2010:46). CSR PAMA KPCS is a division that handles direct relationship with the company stakeholders, including local communities. Issues and crisis which have a direct or indirect relationship, the KPCS PAMA, the CSR division will be followed up. Triple Bottom Line concept is the underlying concept of CSR activities. In the Triple Bottom Line was drawn that something aimed at sustainability, should pay attention to 3P, they are: Profit, People, and Planet.

Profit is a form of responsibility that must achieve by the company, which made even the economic mainstream philosophical footing operations, profit is the main orientation of the company. People are communities where the company is located. They are people who influence and being influenced by the companies. Planet, an elderly physic corporate environment. 
The physical environment has a significant to the existence of the company. Given that, the environment is a place where the company sustains (Hadi, 2010: 58). The main theory that writer used is Crisis Preemptive: Image Management Model (Pang, 2012) in her research Towards a Crisis PreEmptive Image Management Model. This is the main theory that researcher used in this research. Image management model divide crisis into four phases: 1. Before organization event: Proactive phase; 2. Before organization event: Strategic phase; 3. During organization event: Reactive phase; 4. After organization event: Recovery phase. Each of this phase has any different kind of image work with another. Describing of this model can be seen at Picture 2.1:

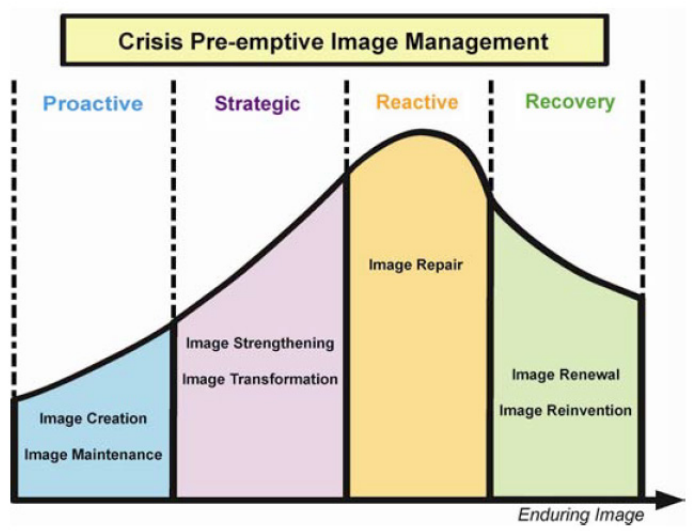

Source: Journal Towards a crisis pre-emptive image management model (Pang: 2012)

Picture 2.1 Crisis Pre-emptive: Image Management Model

Image management takes place on three occasions, before, during, and after organization events. Strategies used before the organization events are anticipatory; strategies used during organization events are in response to the perception threatening events; strategies used after organization events are meant to repair or enhance the organizations image.

There are three approaches to image management. Based on the above discussion, this model posits three organizational approaches to image management over the crisis life cycle:

1. Proactive: The organization is motivat- ed to establishing its image at proactive phase of the life cycle and to differentiate itself from others. The image work undertaken include image creation and image maintenance.

2. Preventive: The organization seeks self-preservation and wants to ensure it remains relevant to its stakeholders at the strategic phase of the life cycle. The image work undertaken includes image strengthening and image transformation.

3. Restorative: The organization seeks to restore order after the crisis is over at the reactive and recovery phases of the life cycle. The image work undertaken includes image, repair, image renewal, and image reinvention, these three approaches can be seen by the picture 2.2 below:

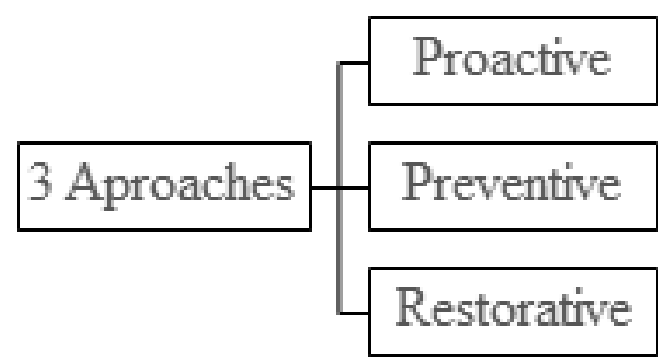

Picture 2.2 Three Approaches in Crisis Pre-emptive Image Management Model

Source: (Pang: 2012)

\section{METHODS}

Research conducted by the writer is a qualitative research. Qualitative research (Kriyantono, 2010: 55) aims to explain the phenomenon of the deepest data collection profusely. This research does not give priority to population size or sampling, but informants are expected to provide the necessary information to get the writer in the research. In this study, the writers collected data by interview, as the main method used. In addition, the researchers also used non-participant observation method, the observation in which researchers do not position themselves as a member of the study group (Kriyantono, 2010: 64). The writer chose 3 PAMA KPCS CSR staff as research informants. 
The informant named Kajan Lahang 1 (40). He is CSR Officer ethnic Dayak Kayan. The writer chose Kajan as one informant because he is a person who has a direct relationship to the local community in Sangatta, East Kutai. Kajan accustomed to the task 'field', and the CSR staff PAMA KPCS the longest tenure. Abdul Syukur is Informant 2 (38). He is Section Head of CSR PAMA KPCS. He is in charge of CSR divisions and create CSR programs. Informant 3 is Suryadi (25). He is an Officer of the CSR field tasks related to the community, and holds administrative duties. Charging KPI (Key Performance Indicator) CSR KPCS PAMA daily, weekly, or monthly, handled by Suryadi. Writers get a lot of data and the conduciveness programs CSR PAMA KPCS in 2010-now, from informant 3.

Besides depth interviews and observations, the writers also do other methods, namely the documentation. Documentation is done in a way the writer took photographs in person at PAMA KPCS. It also optimizes the data taken from the writer's CSR KPI PAMA KPCS since 2010-present.

\section{DISCUSSION}

\section{Before Organizational Event: Proactive Phase}

This is the phase when all appears calm. The organization does not appear to be near any crisis. To prepare for crisis, the organization should embark on environmental scanning for possible issues, how to trade and manage emerging issues, and how to come up with a crisis communication plan (Pang, 2012).

This is what CSR PAMA KPCS do in early March 2010, before crisis happened. What they do is keep the situation and condition conducive. In this proactive phase, they do preventive actions like hearing the issues even big or small. Make a data daily, monthly, even yearly as Key Performance Indicator (KPI) of PAMA KPCS. KPI is filled every day by CSR Officer. Its contents categories crisis to crisis as well as handling the new standard of an issue, there have any relation with PAMA KPCS.

\section{Before Organizational Event: Strategic Phase}

In early March 2010 (the period 2nd8th March 2010), a sound issue. This issue becomes a crisis when a group calling itself the 'Alliance of Indigenous Peoples' came to an external agency KPC (owner of PAMA KPCS), which is located in the city center. They threatened to follow up this issue to the government, if they desire to contribute Rp 10,000/metric ton was not granted KPC. At that time there KPCS PAMA CSR at the strategic phase. Crisis categorized, then the data collection on the incidence and treatment performed as well as next steps.

Strategic event conceptualized by Pang as a time when issues that are likely to emerge as a crisis trigger points are identified. The organization needs to embark on risk communication, conflict positioning (Pang, 2006), and activating the crisis communication plan.

\section{During Organizational Event: Reactive Phase}

In mid-March 2010, CSR PAMA KPCS categorize crisis in the KPC as one of the issues that require the attention of CSR PAMA KPCS. PAMA KPCS also make a repair action to monitor developments related to the group calling itself the Alliance of Indigenous Peoples. Then the external conditions were at the time stated in the prone condition, which means that require special attention.

Continue on May 11, 2010 when the Alliance of Indigenous Peoples at the second demonstration administrative headquarters of KPC (M1 and M2). PAMA KPCS concrete activities in this time of crisis. One of these monitoring points demos and monitor progress in PT KPC and in indigenous communities.

This phase is what Pang said as strategic phase. This is when crisis erupts, the crisis communication plan is activated and the organization should be actively responding 
to the crisis by communicating its actions directly through the media. This is the time when the organization needs to embark on image repair (Pang, 2012).

\section{After Organizational Event: Recovery phase}

After crisis happened in $11^{\text {th }}$ May 2010, PAMA KPCS situation back to normal. Not all the strategic which did by CSR PAMA KPCS being stopped. It is the time to recovery and bring back the situation of company from dangerous condition to conducive. PAMA KPCS make the treatment to the crisis before, until really end. PAMA KPCS also back to the proactive phase, which doing preventive actions to the issue or crisis, even small or big. PAMA KPCS still fill the KPI daily, monthly, or yearly. PAMA KPCS keep monitoring the situation inside or outside the company. CSR run their program as usual, too, and make a preventive actions so the crisis like this, will never happen again.

This phase is described by Pang (2012) as after the crisis over, when the organization takes active steps to restore its battered and bruised reputation. It is also a time of learning from the mistakes made so as to prevent them from occurring again. Instead this study introduced a new concept, drawing on insight from post-crisis discourse, and argues that image renewal ought to take place.

At the community of external condition yearly period in June 2010, it appears the problem on the customer category changed its status from a dangerous condition becomes conducive. This is shown in the box changes color from red state column in May, becoming green in the month of June 2010. Lettered addition of column B which means dangerous to the letter $\mathrm{K}$ which means conducive. The writer conclude, PAMA KPCS already considers this crisis ends in May 2010 and was discontinued in the next month. These conditions can be explained in image management model in this picture 4.1 below:

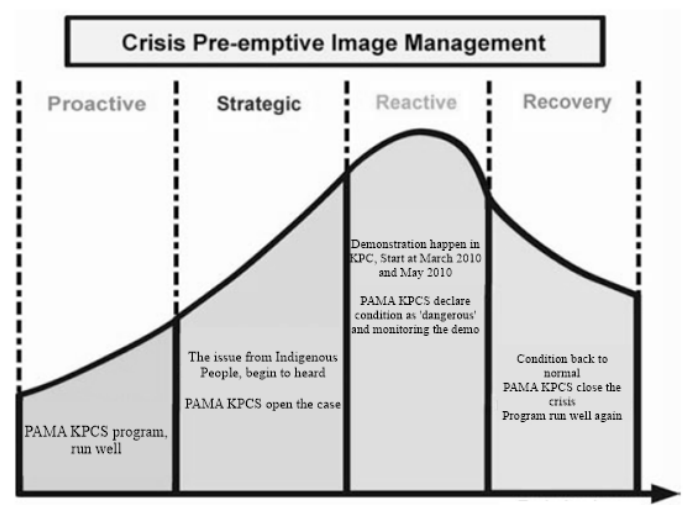

Picture 4.1 PAMA District KPCS Crisis Pre-emptive Image Management Model

Source: Personal by writer

Starts in January - beginning of March 2010 when PAMA KPCS in proactive phase. Then, continue in $2^{\text {nd }}-8^{\text {th }}$ March 2010 when PAMA KPCS in strategic phase. Crisis happen in $27^{\text {th }}$ April 2010 and $10^{\text {th }}$ $11^{\text {th }}$ March 2010. That time, PAMA KPCS in reactive phase and the last phase happened after demonstration or crisis ended. It starts in May and June 2010, when PAMA KPCS do the recovering phase. Scheme in picture 4.2 describes how crisis in PAMA happen:

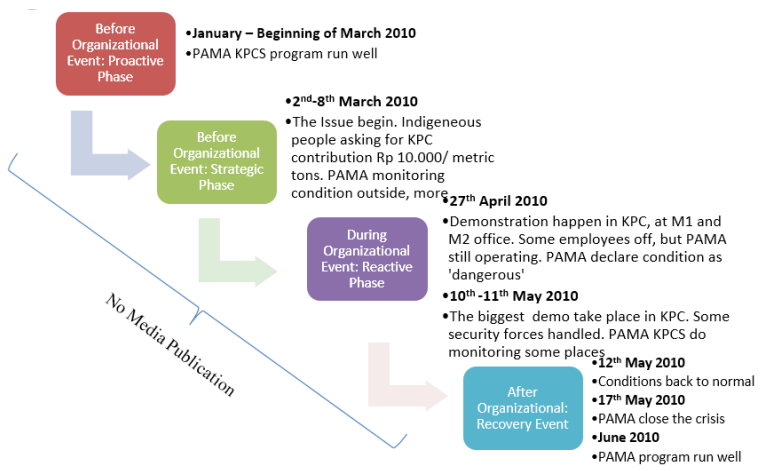

Picture 4.2 PAMA Crisis Pre-emptive: Image Management Model

Source: Personal by writer

\section{E. CONCLUSION}

Crisis preemptive: Image Management Model PAMA KPCS done in treating the crisis in the KPC in 2010. Starting from when the crisis began to be heard, CSR PAMA KPCS write as external conditions are somewhat vulnerable. This is done to maintain stability if at any time PAMA KPCS disturbed. When 
a crisis actually occurs, PAMA KPCS has prepared preventive action to anticipate the crisis that has the possibility of interrupting operations at PAMA KPCS. PAMA KPCS management actions undertaken are, monitor the situation and conditions in PAMA and KPC are used as the point of the demo. Monitoring the progress of the demo at KPC. Finding out the root causes of the demo at KPC and formulate a solution. After the crisis is over, CSR remains PAMA KPCS monitor the situation and external conditions until the crisis actually finished. When the crisis has been completed, PAMA KPCS run the program as usual, as already scheduled CSR goals PAMA. They also fixed the issue of preventive programs run by continuing to hear a small issue, record, and set up a crisis resolution measures.

\section{ACKNOWLEDGMENT}

This thesis is done in a small town called Sangatta, East Kalimantan, and settled in the cultural city called Solo, Central Java. This thesis displays the state of CSR PAMA PERSADA NUSANTARA District KPCS during the crisis in 2008, in Sangatta. But this essay is not resolved simply. Many parties in the settlement very helpful writer of this thesis. Therefore, the writers would like to thank to writer's two supervisor Dian Purworini, and Agus Triyono.

\section{REFERENCES}

Hadi, Nor. 2010. Corporate Social Responsibility. Semarang. Graha Ilmu.

Kriyantono, Rachmat. 2010. TeknikPraktisRisetKomunikasi. Jakarta: Kencana.

Pang, Augustine. 2012. Toward a Crisis Pre-Emptive Image Management Model. Singapore: Emerald Group Publishing Limited.

Regester, Michael dan Judy L. 2005.Risk Issues and Crisis Management in Public Relation: A Casebook of Best Practice. India: Replika Press Pvt Ltd.

Soemirat, Soleh dan Elvinaro A. 2010.Dasar-Dasar Public Relation. Bandung: Rosda. 